\title{
Evaluation of Reproductive Performance and Egg quality Traits in Progenies of Dominant Black Strain Crossed with Fulani Ecotype Chicken
}

\author{
F.E. Sola-Ojo (Corresponding author) \\ Department of Animal Production, University of Ilorin \\ P.M.B 1515 Ilorin, Kwara State, Nigeria \\ Tel: 234-803-821-7248 E-mail: mofesola1@yahoo.com \\ K.L. Ayorinde \\ Department of Animal Production, University of Ilorin \\ P.M.B 1515 Ilorin, Kwara State, Nigeria \\ Tel: 234-803-394-5317 E-mail: tomjay917@yahoo.com
}

\begin{abstract}
This study was undertaken to contribute to the genetic improvement of the indigenous chicken by direct and reciprocal crossing with an exotic egg type strain Dominant Black (DB). Results indicated significant $(\mathrm{P}<0.05)$ effect of genotype on fertility and hatchability of eggs. Percentage fertility across the genotypes was, 73.00, $76.24,59.88$ and $54.12 \%$, while hatchability was $73.90,78.30,70.45$ and $70.10 \%$, for DBxDB, DBxFE, FExDB and FExFE, respectively. There was no significant $(\mathrm{P}>0.05)$ difference in hatch weight of the chicks. The cross bred (DBxFE and FExDB) had higher egg weight (51.45g and $51.35 \mathrm{~g}$ vs. 47.19), total egg number for 100 days (51 and 53 vs. 40 ) and hen day production (50.87 and 52.47 vs. 46.05 ) than the pure bred Fulani Ecotype. FExDB had significantly higher body weight at first egg (1408g) than DBxFE (1388g). Mortality was significantly $(\mathrm{P}<0.05)$ higher in $\mathrm{DBxDB}$ than other genotypes during the laying period. Significant and non significant differences existed in internal and external egg quality traits across the genotypes.
\end{abstract}

Keywords: Cross breeding, Evaluation, Exotic, Indigenous, Egg type, Chicken

\section{Introduction}

Genetic improvement can take many forms, but it must follow an ordered hierarchy of events which starts from understanding of production and marketing systems, choice of appropriate breeds or strains that can sometimes lead to replacements of existing breeds. It can also lead to establishment of an effective pure breeding and cross breeding systems and further improvement through selection of superior genotypes within populations that best suit the production and marketing conditions (Nimbkar, et al., 2008).

The Nigerian indigenous chicken are suitable for the development of layer strain for the tropical environment (Ayorinde, 1986). This is because they possess some inherent advantages which include good fertility and hatchability, better flavour of meat and egg, high degree of adaptability to prevailing condition, high genetic variance in their performance, hardiness, disease tolerance, ease of rearing and ability to breed naturally (Adedeji et al., 2008).

Reports have shown that the indigenous fowl possesses great potentials for genetic improvement through breeding programme such as selection and or cross breeding (Omeje and Nwosu, 1983; Nwosu et al., 1985; Ikeobi et al., 1996; Adebambo et al., 1999; Peters, 2000; Adedeji et al., 2008, Adebambo et al., 2009). Cross breeding of the local stock with an exotic commercial stock could take advantage of artificial selection for productivity in the exotic birds and natural selection for hardiness in the indigenous birds (Adebambo et al.,2009). Moreover, birds with better production performance can result from the combining ability of best performing exotic lines and the indigenous chicken. The economic significance of the reproductive capabilities of laying hens justifies and encourages the study of inheritance of egg production and the relationship with variables associated with the egg production traits. 
The Fulani Ecotype chicken has been reported to have great potentials for genetic improvement in reproductive performance (Atteh, 1990; Tiamiyu, 1999; Olori, 2000; Fayeye et al.,2005; Odetunde, 2007; Sola-Ojo and Ayorinde, 2009). Exploring the potentials of this chicken ecotype through cross breeding will not only lead to improvement of the local chicken but reduce the cost of importation of day old chicks and breeder stock which are costly to manage, especially, in Nigeria. This work was designed to study the performance of pure and cross bred egg-type chickens produced from crossbreeding of the exotic Dominant Black strain and the local Fulani Ecotype chicken.

\section{Materials and Method}

\subsection{Mating Design and Management of Experimental birds}

One hundred and forty three matured Dominant Black (13 males and 130 females) and one hundred Fulani Ecotype (12 males and 88 females) were randomly selected from existing populations and allowed to mate naturally in separate pens at a mating ratio of 1 male to 8 females. The mating groups were:

A. DBxDB (9 DB males and 72 DB females)

B. DBxFE (6 DB males and 48 FE females)

C. FExDB (7 FE males and 56 DB females)

D. FExFE (5 FE males and $40 \mathrm{FE}$ females)

Eggs were collected from each group on daily basis over a 7- day period, labelled according to the group and kept at room temperature prior to incubation. The eggs were taken to a commercial hatchery-Nefraday Farm, Lasoju, Kwara State, Nigeria for incubation and hatching. On arrival, the eggs were allowed to rest, fumigated with $17 \mathrm{~g}$ potassium permanganate and $100 \mathrm{ml}$ of $20 \%$ formalin before incubation. The eggs were candled for fertility on the $18^{\text {th }}$ day of incubation. Three hours before candling, and before transfer of eggs from Setter to Hatcher, $1 \%$ formalin was sprayed in the hatchery room to disinfect the compartment. On arrival, all the chicks obtained were weighed, wing banded, grouped according to genotype and randomly distributed to separate brooding pens. All the necessary vaccinations and medications were administered accordingly. The birds were fed recommended diets (NRC, 1994) from day old to the point of sexual maturity. At 12 weeks of age, male chicks were separated from the females and at $18^{\text {th }}$ weeks of age, all the hens were moved to individual cages for evaluation of reproductive performance.

\subsection{Data collection}

The percentage fertility was calculated by expressing the total number of fertile eggs as a percentage of the total number of eggs set while the percentage hatchability was determined by expressing the total number of hatched chicks as a percentage of total number of fertile eggs. On arrival the weight of each chick was taken as the hatch weight. Other data collected at sexual maturity were body weight at first egg, age at first egg, total number of egg laid for a period of 100 days (Early egg production record), hen day production and percentage mortality. Weight of the eggs laid was determined on daily basis using a sensitive electronic balance (600g capacity).

On weekly basis, three eggs were randomly chosen from each group, weighed, broken and content poured into a Petri dish so as to determine the external and internal egg quality traits. Albumen and yolk were carefully detached with the aid of a spatula and weighed separately. Yolk height and albumen height were measured using a spherometer. The yolk width, egg length and egg width were measured with the aid of vernier callipers. Egg shape index (ESI) was determined according to Reddy et al. (1979), yolk index (YI) was taken as the ratio of yolk height (YH) to yolk width (YWD), while albumen ratio (AR), yolk ratio (YR) and egg shell ratio (ESR) were determined using the method described by Olawumi and Ogunlade (2009). The Haugh Unit values were obtained using the formula $\mathrm{HU}=100 \log \left(\mathrm{H}+7.57,1.7 \mathrm{~W}^{0.37}\right)$ as stated by Oluyemi and Roberts $(2000)$. Where:

$\mathrm{HU}=$ Haugh Unit

$\mathrm{H}=$ Observed height of the albumen (mm)

$\mathrm{W}=$ weight of the eggs in grams.

The shells of the broken eggs were rinsed in warm water, air dried for 48 hours and weighed per replicate to determine the shell weight. Micrometer screw gauge was used to determine the shell thickness from the broad end, narrow end and the middle of the shell, and the average of the three measurements was taken as shell thickness in millimetre. 


\subsection{Statistical Analysis}

Data collected were subjected to one way analysis of variance, using the General Linear Models (GLM) procedure of the Statistical Analysis System (SAS, 2003).

Duncan test was used to separate the means when significant differences existed between them at $5 \%$ significance level. The statistical model used was:

$\mathrm{Y}_{\mathrm{ij}}=\mu+\mathrm{g}_{\mathrm{i}}+\mathrm{e}_{\mathrm{ij}}$;

Where:

$Y_{i j}=$ performance of the $j^{\text {th }}$ individual of the $i^{\text {th }}$ genotype

$\mu=$ general mean of the parameter

$\mathrm{g}_{\mathrm{i}}=$ fixed effect of the genotype $\mathrm{i}(\mathrm{i}=1-4)$

$\mathrm{e}_{\mathrm{ij}}=$ residual error.

\section{Results and Discussion}

3.1 Effect of genotypes on percentage fertility, hatchability, hatch weight, egg production traits and mortality in progenies of Dominant Black strain and Fulani Ecotype chicken

The fertility of total egg sets revealed significant differences $(\mathrm{P}<0.05)$ in the four groups (Table 1). Fertility and hatchability were highest (76.24 and 78.30, respectively) in the crosses involving Dominant Black male and Fulani Ecotype chicken females. These values were significantly $(\mathrm{P}<0.05)$ higher than for other groups. Fertility and hatchability were lowest in the crosses involving Fulani Ecotype male and female, however, there were no significant $(\mathrm{P}>0.05)$ differences in hatchability of eggs obtained from FExDB and FExFE groups. Hatch weight showed no significant $(\mathrm{P}>0.05)$ differences across the genotypes. The hatch weight of the cross bred were similar $(33.04 \mathrm{~g})$ while that of pure Fulani Ecotype chicken group was $0.8 \mathrm{~g}$ smaller than that of pure Dominant Black strain.

The results disagree with that of Dessie and Ogle (2001), who reported higher fertility and hatchability for the local pure bred than in the exotic breeds it also differed from that of Horst (1991) where fertility and hatchability were reported to be higher in local birds. Although, they attributed higher percentage fertility to season and brooding conditions. Kamble et al. (1996) also reported 85\% fertility in Indian full - feathered Kadaknath chicken, $78 \%$ in Dahlem Red and $60 \%$ in Indian naked neck and Aseel hen but low fertility and hatchability among the crosses of those chickens. The implication of our results is that, higher percentage fertility and hatchability is achievable in crosses involving exotic birds with local stocks. Higher percentage hatchability recorded for the FE in this study is in line with earlier findings of ( Fayeye et al., 2005; Alaba, 1990; Atteh,1990) where higher hatchability (70-100\%) were reported for the Fulani Ecotype chicken under natural incubation.

Higher percentage fertility for the crosses where Dominant Black male were involved might be as result of higher body weight of Dominant Black male which allowed good insemination. This is in agreement with the report of Alaba (1990) that high body weight of cocks could lead to higher genital contact and allowed good insemination in chickens. Lower percentage fertility recorded for FExFE groups in this study might be as a results of some non genetic factors imposed on the birds during the experimental period.

Mean of egg production traits are as shown in Table 1. DBxFE and FExDB cross bred hens laid significantly $(\mathrm{P}<0.05)$ bigger eggs than the pure line progenies, but there were no significant differences $(\mathrm{P}>0.05)$ in their egg weights $(51.45 \mathrm{~g}$ and $51.35 \mathrm{~g})$. DBxDB eggs were also not significantly $(\mathrm{P}>0.05)$ bigger than those of FExFE. Egg weight recorded for the purebred and crossbred (47.97 to $51.45 \mathrm{~g}$ ) in this study was higher than 39.75 to 47.0g reported for egg weight in crosses involving local Kadaknath chicken and exotic chickens, and their cross bred progenies (Horst, 1991). Age at sexual maturity was significantly $(\mathrm{P}<0.05)$ influenced by genotypes. DBxDB pure line reached sexual maturity earlier than the other groups. The differences in age at sexual maturity compared to the exotic genotype were 5 days for DBxFE, 8 days for FExDB and 18 days for FExFE. The results indicates that the crossbreds did not perform too poorly with respect to age at sexual maturity.

Body weight at first egg differed significantly $(\mathrm{P}<0.05)$ in the four group. DBxDB started laying at an early age and at lighter body weight than other genotypes. Hen day production (HDP) was similar $(\mathrm{P}>0.05)$ in the DBxDB and DBxFE groups but significantly $(\mathrm{P}<0.05)$ higher than that of FExFE while FExDB had the highest HDP. DBxDB and the cross bred (DBxFE and FEXDB) matured earlier (20 and 21 weeks, respectively) than the FExFE (23weeks). The results obtained for body weight at first egg (BWF) showed that FExDB had the highest BWF (1408g) followed by FExFE (1405g), DBxFE (1388g) and DBxDB (1350g). This showed significant 
$(\mathrm{P}<0.05)$ differences in the weight at the onset of laying. It also indicated that FExFE matured late $(23$ weeks $)$ and required higher body weight threshold for egg laying. The FExDB achieved required body weight at first egg at an early age $(21$ weeks) compared with the FExFE. Mortality was significantly $(\mathrm{P}<0.05)$ higher in the pure bred exotic strain (0.14) than other genotypes.

The total number of eggs laid by the cross bred was higher than those of the pure bred during the early egg production period and this corresponds with the findings of Horst (1991) where higher egg production were recorded for the first 100 days of laying in cross bred progenies of local Kadaknath chicken with exotic New Hampshire and White Leghorn. It was also in line with the findings of Omeje and Nwosu (1983) where the main cross (GLxLC) and the reciprocal cross (LCxGL) had higher egg production than the local chickens.

The mean age at sexual maturity reported for the pure bred FE corresponds with that reported by Fayeye $e t$ al. (2005), Sola- Ojo and Ayorinde (2009) as well as 22 weeks reported for local chicken by Oni et al. (1991), Nwagu et al.(2001) and Yahaya (2008). The lower age at sexual maturity reported for the Dominant Black strain and crossbred correspond with the findings of Singh et al. (1992) where lower age at sexual maturity was reported for White Leghorn chickens and their reciprocal crosses. The non significant differences observed between the FExDB, DBxFE and DBxDB in age at sexual maturity corresponds with the findings of Chaubal et al. (1994) and El-Salamony et al. (2002) where lower age at sexual maturity was reported for cross bred and exotic pure line.

Higher egg production reported for FExDB in this study, is in line with the findings of Zaman et al. (2004) where improvement in egg production was recorded in crossing indigenous naked neck male with an exotic laying strain female. Horst (1991) also reported highest number of egg for the cross bred of naked neck with frizzled feather genotype followed by naked neck with feathered chicken. Egg productions were also found to be significantly higher in cross bred between Indigenous naked neck cocks and exotic hens (Haque and Howlider, 2000). Better egg production recorded in this study agreed with the reports of Huque et al. (2001) and Zaman et al. (2004) where an improvement in egg production were recorded in crosses involving indigenous naked neck male and an exotic laying strain female.

The results of our findings showed that, crossing with the indigenous stock as males, yield better results especially in egg production, while crossing with the improved breed as male led to early age at sexual maturity and smaller body weight at first egg. However, higher age at sexual maturity, smaller egg size and lower hen day production where Fulani Ecotype chicken males and females were involved might be due to the fact that Fulani Ecotype chicken have remained previously unselected for those traits. Zero mortality in FExFE and DBxFE, and low mortality in FExDB showed that pure bred FE and the cross bred adapted favourably to the current environmental condition.

\subsection{Effects of genotypes on Egg quality traits of Dominant Black and Fulani Ecotype chicken progenies}

The mean for the effect of genotypes on external egg quality traits are shown in Table 2. while that of internal egg quality traits are shown in Table 3 . The effects of genotypes differed significantly $(\mathrm{P}<0.05)$ for all the external egg quality traits measured, FExDB was superior in external egg quality traits to other genotypes and were significantly $(\mathrm{P}<0.05)$ different except egg length that was not significantly $(\mathrm{P}>0.05)$ different in FExDB and DBxFE. Significant $(\mathrm{P}<0.05)$ differences also existed in internal egg quality traits (Table 3$)$ with the DBxDB being superior in yolk weight (17.23g), yolk ratio (40.70\%) and yolk index (66.22\%) to DBxFE and FExFE. For other traits such as yolk height, albumen height, albumen weight and Haugh unit, the FExDB was superior to other genotypes. The FExDB did not differ significantly $(\mathrm{P}>0.05)$ from DBxFE in yolk width and albumen height. While the DBxFE differed significantly $(\mathrm{P}<0.05)$ from FExFE in albumen weight, Haugh unit, albumen ratio, yolk ratio, there were no significant differences in their yolk index and yolk height. FExFE was significantly $(\mathrm{P}<0.05)$ superior in shell thickness than other genotypes. The crossbred also had better shell thickness compared to pure bred Dominant Black.

The significant genotype effect obtained in this study for shell ratio agrees with the findings of Fletcher et al. (1981) and that of Olawumi and Ogunlade (2009) where significant breed effects were reported for egg quality traits in some exotic breeds of chicken. The genetics differences in yolk weight, albumen weight and albumen height obtained in this study also agree with the findings of Islam et al. (2001) where significant differences were reported in egg weight and quality traits of indigenous naked neck and indigenous full feathered. The values obtained for yolk ratio also agree with the reports of Pandey et al.(1986) that strain differences existed in yolk of eggs. 
The genotypic differences in Haugh unit obtained in this study confirm the past reports of Hill (1977) and Zaman et al. (2004) where different Haugh unit values were reported for various strains of birds. However, the results obtained for egg length contradict the findings of Prasad et al. (1981) where no breed effects were reported for that trait. The existing similarity of the values obtained for yolk width and albumen height in the FExDB and DBxFE contradicts the findings of Islam et al. (2001) where significant differences were reported for those traits in indigenous naked neck and indigenous full feathered chickens.

The Haugh unit values obtained for the cross bred and pure bred eggs were above 70. This is an indication of eggs with better albumen quality (North, 1984). The findings showed that both the Fulani Ecotype chicken male line and the female line combined favourably in the quality of eggs produced.

\section{Conclusion}

The results of this work showed higher percentage fertility and hatchability in crosses between Dominant Black strain and Fulani Ecotype chicken. Fulani Ecotype chicken male line had the highest number of egg production, pure bred Dominant Black strain was superior to the pure bred Fulani Ecotype chicken in egg production, while the Fulani Ecotype chicken female line had the same production rate as the pure bred exotic line.

The cross bred lines produced larger eggs, had lower mortality rate and did not perform poorly in age at sexual maturity and body weight at first egg compared to the pure bred exotic line. Pure bred Fulani Ecotype chicken and the cross bred adapted very well to the environmental conditions where the study was carried out. It was observed that cross breeding of the Dominant Black strain (an exotic egg type chicken) and the Fulani Ecotype (a local chicken) produced an egg type chicken with better productivity and adaptability in tropical environment.

\section{Acknowledgements}

The authors would like to thank the Management of S and D Farm Ltd. Aderupoko, Abeokuta, Ogun state, Nigeria for providing day old chicks of Dominant Black Strain (Parent stock) used for this research.

\section{References}

Adedeji, T.A., Ojedapo, A.O., Ige, S.A., Akinwunmi, A.O and Amao, S.R. (2008). Genetic evaluation of growth performance of pure and crossbred chicken progenies in a derived savannah environment. Proc. of the $13^{\text {th }}$ Annual Conference of the Animal Science Association of Nigeria, (ASAN), Sept. 15 -19. ABU Zaria : 8-12.

Adebambo, O.A., Ikeobi, C.O.N., Ozoje, M.O and Adenowo, J.A. (1999). Colour variation and performance characteristics of the indigenous chicken of south western Nigeria. Nig. Journal of Animal Production, 26: 1522.

Adebambo, O.A., Ikeobi, C.O.N., Ozoje, M.O and Adebambo, O.A. (2009). Variation in growth performance of pure and crossbred meat type chickens. Nig. Journal of Animal Production, 36. (2): 211- 227.

Alaba, A.O. (1990). Fertility and Hatchability of eggs from Cross Breeding Dahlem Red and Local chicken. $B$. Agric Project Report, OAU, Ile Ife, Pp 40-65.

Atteh, J.O. (1990). Rural Poultry Production in Western Middle belt region of Nigeria. In: Proc. of International workshop on Rural Poultry in Africa. (Ed. Sonaiya, E.B), Nov 13-16, 1989, Ile- Ife, Nigeria: 211-220.

Ayorinde, K. L. (1986). Poultry for Protein. African Farming and Food Processing Sept/ Oct. 1986: 17-18.

Chaubal, D.V, Solnki, J.V. Shukai, R.K, Rank, D.N. Misshra, R.K and Khama, K. (1994). Performance of White leghorn pullets under reciprocal recurrent selection for two generations. Indian Journal of Poultry Science, 28 (3):211-217.

Dessie, T. and Ogle. B. (2001). Village Poultry Production System in the Central Highlands of Ethiopia. Tropical Animal Health and Production, 33: 521-537.

El - salamony, A.I., Abou- Ahour, A.M and Ezzeldin, Z.A. (2002). A study of heterosis in some egg production traits in Norfa layers. Egypt. Journal of Agric. Res., 80 (3): 1337- 1352.

Fayeye, T.R., Adeshiyan, A.B and Olugbami, A.A. (2005). Egg traits, hatchability and early growth performance of the Fulani - Ecotype Chicken. Livestock Research for Rural Development. http:// www.lrrd. org/lrrd17/8faye17094.htm.LRRD.17 (8).

Fletcher, D.L., Britton, W.M., Rahn, A. P and Savage, S.I. (1981). The influence of layer flock age on egg component yields and solids content. Poultry Science, 60 (5): 983- 987.

Haque, M.F and Howlider, M.A.R. (2000). Growth and meat yield in native naked neck, exotic chicken and their crossbreds. $\mathrm{F}_{2}$ generation. Indian Journal of Animal Science, 70: 501- 503. 
Hill, T. (1977). The effects of space allowance and group size on egg production traits and profitability. British Poultry. Sci., $18: 483-492$.

Horst, P. (1991). Native fowl as a reservoir for genomes and major genes with direct and indirect effects on productive adaptability and their potential for tropically oriented breeding plans - A review of Animal Research and Development, 33: 63-79.

Ikeobi, C.O.N., Ozoje, M.O., Adebambo, O.A., Adenowo, J.A and Osinowo, O.A. (1996). Genetic differences in the performance of the local chicken in south western Nigeria. Nig. journal of Genetics, 11: 55- 60.

Islam, M.A Bulbul, S.M, Seeland, G. and Islam A.B.M.M. (2001). Egg quality of different chicken genotypes in summer and winter. Pakistan Journal of Biological Sciences, 4: 1411- 1414.

Kamble, K.D., Singh, D.P., Jori, D.C and Sharma R.D. (1996). Reproductive performance of Various Indian native breeds and their crosses with Dahlem Red. Proc. of the XX world's Poultry Congress, New Delhi, India, 2-5 September, Vol-14 : 36 .

Nimbkar, C. Gibson, J. Okeyo, M. Boettene, P and Soelknor J. (2008). Sustainable use and genetic Improvement. Animal Genetic Resources Information AGRI, 2008, 42: 49 - 69.

North, O.M. (1984). Commercial chicken production manual $3^{\text {rd }}$ Edition AVT Publishing company California. Pp 291

Nwagu, B.I, Nwosu C.C, Abubakar, B.Y, Oni O.O and Adeyinka, I.A. (2001). Productive Performance of $F_{1}$ Crosses between Arbor Acre Broilers and Local Chickens of Nigeria. Journal of Animal Production, 17 (1 \& 2): 66-77.

Nwosu, C.C Gowen, F.A Obioha, F.C Akpan, I.A and Onuora, G.I. (1985). Biometrical study of the conformation of the native chicken. Nig. Journal of Animal production, 12: 141- 146.

NRC. (1994). National Research Council 1994. Nutrient Requirement Table of poultry. $9^{\text {th }}$ Ed. Washington, D.C. National Academy Press.

Odetunde, R.B. (2007). Comparative studies of two indigenous chicken in Kwara State, B. Agric. thesis Department of animal Production University of Ilorin. Pp 35-40.

Olawumi, S.O and Ogunlade J.T. (2009). The effects of genotype and Age of layer Breeders on Egg quality Traits. Nig. Journal of Animal Production, 36 (2): 228- 236.

Olori,V.E. (1994). Quantitative variation in the Nigerian indigenous chicken : Juvenile growth characteristics. Proc. of the $5^{\text {th }}$ World Congress on Genetics Applied to livestock Production, Guelph, Canada, Vol. 20 : $417-$ 420.

Oluyemi, J.A and Roberts F.A. (2000). Poultry Production in warm - wet climate. Spectrum Books Ltd., Ibadan, Nigeria.

Omeje, S.S.I and Nwosu, C.C. (1983). Egg production patterns in local chickens and their crosses in short term. Nig. Journal of Animal Production, 10: 91-96.

Oni, O.O., Abubakar, B.Y and Ogundipe, S.O. (1991). Genetic and phenotypic association of juvenile body weight and egg production traits in two strains of Rhode Island Chickens, Nig. Journal of Animal Production, 18: 66-70.

Pandey, N.K.M., Mahaparta, C.M., Verma, S.S and Johar, A. (1986). Effect of strain on physical egg quality characteristics in White Leghorn Chickens. Ind. Journal of Poultry Sci., 21: $304-307$.

Peters S.O. (2000). Genetic variation in the reproductive performance of indigenous chicken and the growth rates of its pure and half bred progeny. M.Sc. Thesis. Dept of Anim. Breeding and Genetics University of Agriculture. Abeokuta. Pp 120.

Prasad, A.J., Kothandaraman, P., Kadirvel, R and Krishnan A.R. (1981). Influence of strain, housing and season on egg quality traits in White Leghorn pullets. Cheiron, 10: 63 - 66.

Singh, D.P., Chaudhary, M.L., Brah, G.S and Sandhu, J.S. (1992). Evaluation of two White leghorn strains and their reciprocal crosses for part year production. Indian Journal of Poultry Science, 27(3) :139-143.

Reddy, P.M., Reddy, V.R, Reddy, C.V and Rap, P.S. (1979). Egg weight, shape index, and hatchability in Khaki Campbell duck egg. Indian Journal of Poultry Science, $14: 26-31$.

SAS. (2003). SAS. Users guide statistical Analysis. Inst. Inc. Cary. North Carolina. 
Sola- Ojo, F.E and Ayorinde, K.L. (2009). Comparative performance of two indigenous chicken in Kwara state. In: Global food Challenges (Umoh, B.I, Solomon, I.P Udedibe A,B.I, Obasi, O.L Okon, B.I and Udoh E.J. eds.). Proc. $34^{\text {th }}$ annual conf. of Nigerian Society For Animal Production. (NSAP) University of Uyo, Akwa Ibom $15^{\text {th }}$ $18^{\text {th }}$ March (2009): 463-465.

Tiamiyu, A.K. (1999). Morphological features of Fulani Ecotype Chicken. Proc. of the 26th annual NSAP conf. March $17^{\text {th }}-23^{\text {rd }} 1999$, Ilorin Kwara State, Nigeria : 21-25.

Yahaya, H.K. (2008). Performance of Layer chicken under short term reciprocal recurrent selection. Proc. $32^{\text {nd }}$ Annual conf. Genetics society of Nigeria (GSN) UDUS, Sokoto state, Nigeria: 127-132.

Zaman, M.A., Sorensen, P. and Howlider, M.A.R. (2004). Egg production performance of a breed and three crossbreds under semi- scavenging systems of management. Livestock Research for Rural Development. 16: www. Cipav. Org.co.Lrrd 16/8/Zama/16060. htm.

Table 1. Effect of genotype on fertility, hatchability, hatch weight, egg laying performance and mortality in crosses between the Fulani Ecotype chicken and Dominant Black strain

\begin{tabular}{lllll}
\hline \multirow{2}{*}{ TRAITS } & \multicolumn{3}{l}{ GENOTYPES } & \\
\cline { 2 - 5 } & DBxDB & DBxFE & FExDB & FExFE \\
\hline Fertility (\%) & $73.00 \pm 10.16^{\mathrm{b}}$ & $76.24 \pm 11.69^{\mathrm{a}}$ & $62.88 \pm 2.24^{\mathrm{c}}$ & $54.12 \pm 1.23^{\mathrm{d}}$ \\
Hatchability (\%) & $73.90 \pm 8.81^{\mathrm{b}}$ & $78.30 \pm 8.95^{\mathrm{a}}$ & $70.47 \pm 6.74^{\mathrm{c}}$ & $70.10 \pm 9.33^{\mathrm{c}}$ \\
Hatch weight (g) & $33.97 \pm 6.70$ & $33.04 \pm 8.11$ & $33.04 \pm 8.10$ & $33.17 \pm 4.47$ \\
EW (g) & $47.25 \pm 1.25^{\mathrm{b}}$ & $51.45 \pm 2.5^{\mathrm{a}}$ & $51.35 \pm 1.2^{\mathrm{a}}$ & $47.19 \pm 0.7^{\mathrm{b}}$ \\
ASM (days) & $140 \pm 5.50^{\mathrm{d}}$ & $145 \pm 2.00^{\mathrm{c}}$ & $148 \pm 3.56^{\mathrm{b}}$ & $158 \pm 3.25^{\mathrm{a}}$ \\
BWF (g) & $1350 \pm 1.50^{\mathrm{c}}$ & $1388 \pm 1.02^{\mathrm{b}}$ & $1408 \pm 0.98^{\mathrm{a}}$ & $1405 \pm 0.73^{\mathrm{a}}$ \\
TEN/ hen.(100days) & 51.00 & 51.00 & 53.00 & 40.00 \\
HDP(\%) & $51.54 \pm 1.25^{\mathrm{b}}$ & $50.87 \pm 0.35^{\mathrm{b}}$ & $52.47 \pm 1.75^{\mathrm{a}}$ & $46.05 \pm 1.48^{\mathrm{c}}$ \\
& & & & \\
Mortality (\%) & $14.00^{\mathrm{a}}$ & $0.00^{\mathrm{c}}$ & $4.00^{\mathrm{b}}$ & $0.00^{\mathrm{c}}$ \\
\hline
\end{tabular}

${ }^{\text {(a-d) }}$ Means on the same row with different superscript differs significantly.

$\mathrm{EW}=$ Egg weight, $\mathrm{ASM}=$ Age at Sexual Maturity, $\mathrm{BWF}=$ Body weight at First Egg, $\mathrm{TEN}=$ Total Egg Number, $\mathrm{HDP}=$ Hen Day Production.

DBXDB $=$ Dominant Black male and female

DBXFE $=$ Dominant Black male and Fulani Ecotype female

FEXDB $=$ Fulani Ecotype male and Dominant Black female

FEXFE $=$ Fulani Ecotype male and female 
Table 2. Effect of genotype on External egg quality traits of the cross bred (DB vs. FE)

\begin{tabular}{lllll}
\hline Traits & DBXDB & DBXFE & FEXDB & FEXFE \\
\hline EW $(\mathrm{g})$ & $42.25 \pm 1.25^{\mathrm{b}}$ & $48.35 \pm 1.26^{\mathrm{c}}$ & $52.45 \pm 2.11^{\mathrm{a}}$ & $38.99 \pm 0.78^{\mathrm{d}}$ \\
EL $(\mathrm{cm})$ & $3.84 \pm 0.01^{\mathrm{b}}$ & $3.94 \pm 0.03^{\mathrm{a}}$ & $4.08 \pm 0.03^{\mathrm{a}}$ & $3.86 \pm 0.01^{\mathrm{c}}$ \\
EWD $(\mathrm{cm})$ & $2.24 \pm 0.02^{\mathrm{b}}$ & $2.00 \pm 0.02^{\mathrm{c}}$ & $2.46 \pm 0.01^{\mathrm{a}}$ & $2.24 \pm 0.01^{\mathrm{b}}$ \\
ESW $(\mathrm{g})$ & $4.29 \pm 0.02^{\mathrm{c}}$ & $4.89 \pm 0.03^{\mathrm{b}}$ & $5.26 \pm 0.03^{\mathrm{a}}$ & $4.06 \pm 0.01^{\mathrm{d}}$ \\
EST (mm) & $0.40 \pm 0.01^{\mathrm{d}}$ & $0.46 \pm 0.01^{\mathrm{c}}$ & $0.53 \pm 0.01^{\mathrm{b}}$ & $0.59 \pm 0.02^{\mathrm{a}}$ \\
ESI (\%) & $58.24 \pm 0.33^{\mathrm{b}}$ & $50.96 \pm 0.04^{\mathrm{c}}$ & $60.78 \pm 0.43^{\mathrm{a}}$ & $58.03 \pm 0.05^{\mathrm{b}}$ \\
ESR (\%) & $8.89 \pm 0.28^{\mathrm{c}}$ & $9.28 \pm 0.10^{\mathrm{b}}$ & $9.84 \pm 0.09^{\mathrm{a}}$ & $8.87 \pm 0.07^{\mathrm{c}}$ \\
\hline
\end{tabular}

${ }^{(\mathrm{a}-\mathrm{d})}$ Means in the same column with different superscript differs significantly $(\mathrm{P}<0.05)$.

EW $=$ Egg Weight, EL =Egg Length, EWD=Egg Width, ESW= Egg Shell Weight, EST= Egg Shell Thickness.

DBXDB $=$ Dominant Black male and female

DBXFE $=$ Dominant Black male and Fulani Ecotype female

FEXDB $=$ Fulani Ecotype and Dominant Black female

FEXFE $=$ Fulani Ecotype male and female

Table 3. Effect of genotype on Internal egg quality traits of the cross bred (DB vs. FE)

\begin{tabular}{lllll}
\hline Parameters & DBXDB & DBXFE & FEXDB & FEXFE \\
\hline YW (g) & $17.23 \pm 1.44^{\mathrm{a}}$ & $16.55 \pm 0.68^{\mathrm{c}}$ & $16.83 \pm 0.02^{\mathrm{b}}$ & $14.90 \pm 1.94^{\mathrm{d}}$ \\
YWD (cm) & $2.75 \pm 0.03^{\mathrm{b}}$ & $2.80 \pm 0.01^{\mathrm{a}}$ & $2.82 \pm 0.02^{\mathrm{a}}$ & $2.78 \pm 0.01^{\mathrm{b}}$ \\
YH (cm) & $1.65 \pm 0.03^{\mathrm{b}}$ & $1.60 \pm 0.03^{\mathrm{b}}$ & $1.81 \pm 0.02^{\mathrm{a}}$ & $1.60 \pm 0.03^{\mathrm{b}}$ \\
AH (cm) & $0.78 \pm 0.67^{\mathrm{b}}$ & $0.85 \pm 1.00^{\mathrm{a}}$ & $0.85 \pm 0.83^{\mathrm{a}}$ & $0.78 \pm 0.13^{\mathrm{b}}$ \\
AW (g) & $20.50 \pm 3.93^{\mathrm{d}}$ & $25.65 \pm 3.18^{\mathrm{b}}$ & $26.55 \pm 3.82^{\mathrm{a}}$ & $21.53 \pm 3.06^{\mathrm{c}}$ \\
HU & $83.07 \pm 0.91^{\mathrm{a}}$ & $77.28 \pm 0.94^{\mathrm{c}}$ & $83.60 \pm 0.94^{\mathrm{a}}$ & $79.88 \pm 0.98^{\mathrm{b}}$ \\
AR (\%) & $48.70 \pm 0.46^{\mathrm{d}}$ & $53.48 \pm 0.28^{\mathrm{b}}$ & $49.67 \pm 0.46^{\mathrm{c}}$ & $55.22 \pm 0.30^{\mathrm{a}}$ \\
YR (\%) & $40.70 \pm 0.98^{\mathrm{a}}$ & $34.35 \pm 0.65^{\mathrm{c}}$ & $31.48 \pm 0.73^{\mathrm{d}}$ & $38.25 \pm 0.49^{\mathrm{b}}$ \\
YI (\%) & $66.22 \pm 0.08^{\mathrm{a}}$ & $57.34 \pm 0.13^{\mathrm{c}}$ & $63.18 \pm 0.06^{\mathrm{b}}$ & $57.53 \pm 0.08^{\mathrm{c}}$ \\
\hline
\end{tabular}

${ }^{(\mathrm{a}-\mathrm{d})}$ Means in the same column with different superscript differs significantly $(\mathrm{P}<0.05)$. YW $=$ Yolk weight, $\mathrm{YWD}$ $=$ Yolk width, $\mathrm{YH}=$ Yolk heights, $\mathrm{AH}=$ Albumen heights, $\mathrm{AW}=$ Albumen weights, $\mathrm{HU}=$ Haugh units, $\mathrm{AR}=$ Albumen ratio $\mathrm{YR}=$ Yolk ratio, $\mathrm{YI}=$ Yolk index.

DBXDB $=$ Dominant Black male and female

DBXFE $=$ Dominant Black male and Fulani Ecotype female

FEXDB $=$ Fulani Ecotype and Dominant Black female

FEXFE $=$ Fulani Ecotype male and female 